IRA-International Journal of Technology \& Engineering ISSN 2455-4480

Proceedings of the International Conference on Science \& Engineering for Sustainable Development (2017)

Pg. no.295-317

Published by: Institute of Research Advances https://research-advances.org/index.php/IRAJTE

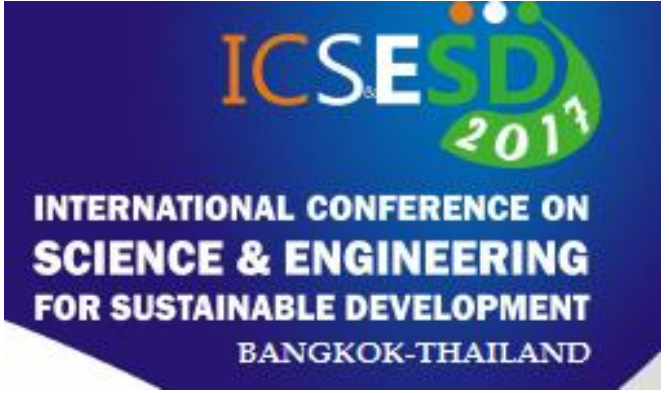

\title{
Energy Environment Interaction Analysis in Thermal Power Plant: A Case Study of TPP with Energy Audit Approach in Indian Scenario
}

\author{
Anil B. Onkar ${ }^{1}$, Gunwant A.Dhomane ${ }^{2}$, Ravindra M .Moharil ${ }^{3}$ \\ ${ }^{1}$ Additional Executive Engineer at MSPGCL (M.S.INDIA) onkaranil63@gmail.com \\ ${ }^{2}$ Prof. in electrical engineering at govt. college of engineering chandrapur ( M.S., \\ INDIA)gadhomane@gmail.com \\ ${ }^{3}$ Prof. in electrical engineering at YCCE, Nagpur( M.S., INDIA) \\ rmm_ycc_ep@yahoo.com
}

Type of Review: Originality Check \& Peer Review under the responsibility of the Scientific Committee of the Conference and The Institution of Engineers (India).

DOI: http://dx.doi.org/10.21013/jte.ICSESD201729

\section{How to cite this paper:}

Onkar, A., Dhomane, G., Moharil, R. (2017). Energy Environment Interaction Analysis in Thermal Power Plant: A Case Study of TPP with Energy Audit Approach in Indian Scenario. Proceedings of the International Conference on Science \& Engineering for Sustainable Development (2017), 295-317. doi: http://dx.doi.org/10.21013/jte.ICSESD201729

(C) International Conference on Science \& Engineering for Sustainable Development \& The Institution of Engineers (India).

\section{(cc) BY-No}

This work is licensed under a Creative Commons Attribution-Non Commercial 4.0 International License subject to proper citation to the publication source of the work.

Disclaimer: The conference papers as published by the Institute of Research Advances (IRA) are the views and opinions of their respective authors and are not the views or opinions of the IRA. The IRA disclaims of any harm or loss caused due to the published content to any party. 


\section{ABSTRACT}

Engineering based on basic principle of combustion process ,associated thermodynamics, \& basic engineering principles involved in optimization of heat rate and in-house auxiliary consumption as energy input (i.e. coal consumption \& in-house auxiliary consumption). Strong theme behind this paper is actual implementation of academic knowledge with practical working experience in thermal power plant .whole paper is associated with reduction of coal, electrical energy input spent on in-house auxiliaries which ultimately reduces greenhouse emission \& helps to maintain environment by upgrading knowledge \& working experience of Engineer working with TPP.

Keywords: Heat rate (kcal/kwh), calorific value(Kcal/kg),VFD( variable frequency Drive), CDM ( Clean development Mechanism),PLF( Plant load Factor ),TPP( Thermal power plant ), CSTPS( Chandrapur Super Thermal Power Station), B.E.E(Bureau Of Energy Efficiency), MERC(Maharashtra Electricity Regulatory Comission),PAT (Perform Achieve \& Trade),AVF(Avialable Factor).

\section{Introduction}

Availability of Power has a crucial rule in economic development of the country. In today's world energy is very precious. India ranks fifth in the world in total energy. A famous quote "Energy saved is energy generated" this shows that apart from increasing generation capacity at higher cost one most go for Energy Audit to save the electricity at much lower cost. A well done energy audit will always help owners to understand more about the ways energy is used in their organizations and help to identify areas where waste can occur. The Energy is the translation of conversation ideas and hopes into reality by leading technically feasible solutions. About $70 \%$ of energy generation capacity is from fossil fuels in India. India has been of the world's fastest growing energy markets due to rapid economic expansions. It is expected to be the second larger contributor to increase in Global energy demand by 2035. The world today acknowledges that the guiding concept for the future is SUSTAINABLE Development. Where industrial growth is linked to husbanding of the earth's resources. Negotiation on the Kyoto protocol to the United Nation Framework Convention on Climate Change (UNFCCC) were completed on December- 11, 1997 Committing the industrialized nation to specify legally binding reduction in emission of six greenhouse gases i.e. CO2, NOX, SOX, HFCS, and PFCS \& SF6. The present study has been undertaken in such of reduction in specific coal consumption \& Auxiliary Power consumption in Thermal Power Plant. Per capita GHG emissions of India are estimated to be 2.1 Tone of $\mathrm{CO} 2$ in the year 2020 and 4.5 tone of $\mathrm{CO} 2$ in the year2030. The key drives of the range of this estimated are the assumption on GDP growth rates. Penetration of clean energy assumed energy efficiency improvements. Present GHG emission is 2.61 billion tone of $\mathrm{CO} 2$ (2016) will rise upto7.3 billion of CO2e in 2031-32 and fall in CO2 Intensity from $0.37 \mathrm{~kg}$ of $\mathrm{CO} 2$ to $0.28 \mathrm{~kg}$ of CO2 per GDP from 2001-02 to 2031-32 as per TERI POZNAM model study which considered only limited improvement in energy efficiency based on past trends \& expert judgment considering level of maturity of specific technology in India. But as per TERI MOEF model CO2 intensity will fall from $0.37 \mathrm{~kg} \mathrm{CO} 2$ to $0.18 \mathrm{~kg} \mathrm{CO} / \mathrm{GDP}$ from 2001-02 to 2031-32. But this study considers energy efficiency improvement in specific technologies.[1,2]BEE launched the PAT program under NMEEE in 2012, as a part of CDM.

\section{REVIEW OF PREVIOUS WORK}

Environmental challenges to thermal power industries in India is already carried out [3]impact of advanced control solution \& control loops is suggested in previous work [4] Use of data envelope Analysis ( DEA) for calculating technical efficiency for decision making is suggested [5] study related to use of imported 
coal \& its impact on environment in Indian scenario is already studied [6] Model related to GHG emission calculation which provides useful tool for inventory preparation [7,9] problem related with fly ash \& its utilization is discussed previously[8] Environmental benefit using supercritical Technology [10].In my paper actual problem related with work experience \& its impact on input coal consumption with the help of engineering principles is discussed in detail .My paper is really helpful to fill the gap in literature review.

The PAT scheme currently identified 478 designated consumers from eight energy intensive industrial sectors namely Thermal Power Plant, Iron \& Steel, Cement, Textiles, Chlor-Alkali, Aluminum fertilizers, pulp \& paper. BEE has targeted 6.6 million mtoe to be saved by the scheme over the first cycle\& multifold rise in saving expected in further cycles out to 2020. Thermal Power Plant are coming under the energy conservation act as a designated customer under the mandate of the energy conservation act 2001 the BEE is implementing various activities to provide momentum to the energy efficiency movement in the country with the view to enhance operating efficiency, reduce operating costs, minimize the emission of GHG and induce competitive cutting edge for the users.

Coal fired Thermal Power Plant unit enjoy lion's share in Indian energy Scenario of the total 285173 MW. Maharashtra having Thermal installed capacity for generation over 26478 MW out of 40589 MW total installed capacity MERC approved normative parameters are Unit Heat Rate, Auxiliary Power, Specific Oil Consumption, and PLF. Energy efficiency is the least expensive way for power \& process industries to meet a growing demand for cleaner energy. The IEA (International Energy Agency) 2006 energy technology perspectives model is a bottom up, least cost, Optimization program. The model was developed to describe the global potential for energy efficiency and $\mathrm{CO}_{2}$ emission reduction in the period to 2050 particularly in Industrial Sector. As per this model $\mathrm{CO}_{2}$ emissions are stabilized globally in 2050 to 2005.level and world narrowly avoids a costly climate crisis.

\section{A. All India Installed Capacity of Power Station}

All India installed capacity for coal based gas, diesel. Nuclear. Hydro; renewable energy by ministry of new and renewable energy (MNRE) as on 31.03.2016 is shown in Table I as per (CEA report 2016) and associated bar graph is also shown in fig.1

TABLE I

MODE WISE CONTRIBUTION IN PERCENTAGE (ALL INDIA) AS ON 31.03.2016

\begin{tabular}{|l|l|}
$\begin{array}{l}\text { TYPES OF GENERATION AND } \\
\text { INSTALLED CAPACITY IN MW }\end{array}$ \\
Coal Based & 185172.88 \\
\hline Gas & 24508.63 \\
\hline Diesel & 993.53 \\
\hline Nuclear & 5780.00 \\
\hline Hydro & 42783.42 \\
\hline RES (MNRE) & 42849.38 \\
\hline Grand Total & 302087.84 \\
\hline
\end{tabular}




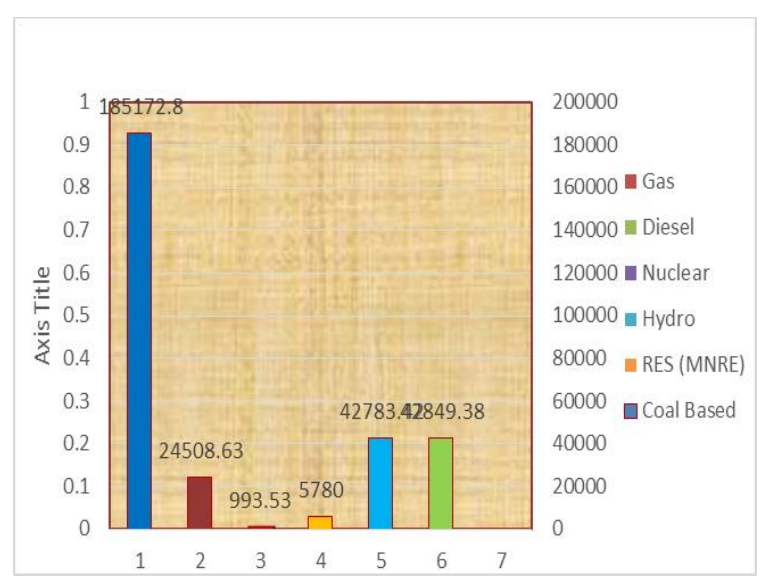

Fig 1. Bar graph for mode wise contribution in India

B. All Maharashtra State Installed Capacity of Power Station

Maharashtra state capacity for coal based, gas, diesel nuclear hydro \& renewable energy as on 31.03.2016 is shown in table II as per (CEA report 2016) and associated bar graph is also shown in fig 2

TABLE II

MODE WISE CONTRIBUTION IN PERCENTAGE (IN MAHARASHTRA) AS ON 31.03.2016

\begin{tabular}{|l|l|}
\hline \multicolumn{2}{|l|}{ TABLE 2 } \\
\hline TYPES OF & GENERATION AND \\
INSTALLED CAPACITY IN MW \\
\hline Coal Based & 26478.26 \\
\hline Gas & 3475.93 \\
\hline Diesel & 0 \\
\hline Nuclear & 690.14 \\
\hline Hydro & 3331.84 \\
\hline RES (MNRE) & 6613.29 \\
\hline Grand Total & 40589.46 \\
\hline
\end{tabular}

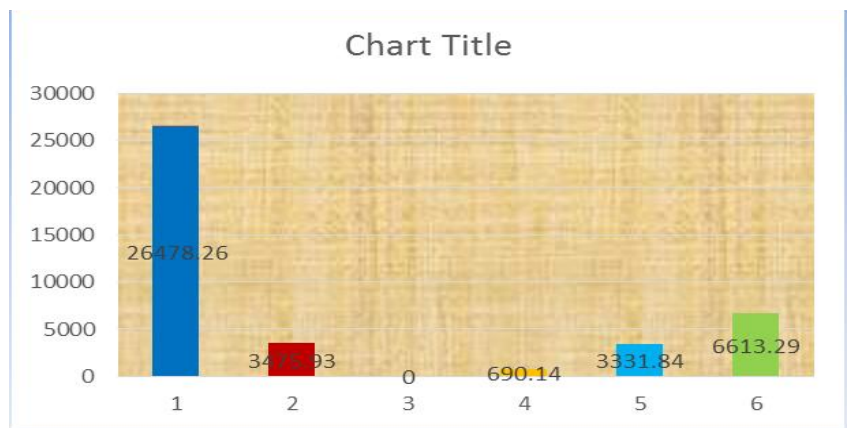

Fig2.bar graph for Mode-wise Contribution in Percentage (in Maharashtra)

C. Importance Of Energy Efficiency 
The International Energy Agency's "Accelerated Technology Scenario" suggests that Power Generation Efficiency can contribute significantly to the overall global effect to stabilize $\mathrm{CO}_{2}$ emission by 2050 at or near to 2005 level model shows that "Power Generation Efficiency" alone which includes improved auxiliaries and other reduction measures has a larger climate impact than even nuclear power.

TABLE III

PERCENTAGE OF GLOBAL EFFECT TO STABILIZE CO2

\begin{tabular}{|c|c|c|c|c|}
\hline \multicolumn{5}{|l|}{ Table 3} \\
\hline $\begin{array}{l}\text { Product } \\
\text { Efficiency }\end{array}$ & $\begin{array}{l}\text { Energy \& } \\
\text { Feed stock } \\
\text { substitution }\end{array}$ & $\begin{array}{l}\mathrm{CO} 2 \\
\text { Capture } \\
\& \\
\text { Storage }\end{array}$ & $\begin{array}{l}\text { Process } \\
\text { innovation }\end{array}$ & $\begin{array}{l}\text { Energy } \\
\text { Efficiency }\end{array}$ \\
\hline $5 \%$ & $20 \%$ & $22 \%$ & $4 \%$ & $49 \%$ \\
\hline
\end{tabular}

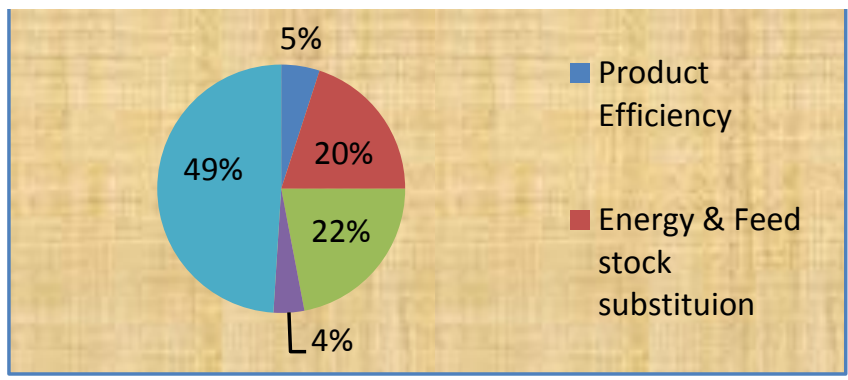

Fig 3. Piechart percentage of global effect to stabilize $\mathrm{CO}_{2}$

\section{Power Plant Processes}

In a thermal power plant various processes are carried out as shown in table IV. The coal is conveyed then it is crushed to a smaller size. Coal mills are provided to pulverize the coal to 200 mesh size and carried in a very fine powdered form to the boiler which produces steam. Feed water for boiler is preheated to get better cycle efficiency. Steam covering out from the boiler is super-heated before admitting to the turbine.

After performing work in a high pressure turbine the exhaust steam is again reheated to $540{ }^{0} \mathrm{C}$ and then admitted in intermediate pressure turbine from intermediate pressure turbine steam goes to low pressure turbine and then exhaust steam is condensed to water and this water is again used as a feed water for the boiler.

Various activities is explained as follows

1) Conveying \& preparing the fuel.

2) Moving necessary air to the furnace

3) Moving flue gas from the furnace

4) Returning the condensed water back to the steam generator

5) Maintaining the necessary cooling effect in the condenser

6) Operating various emission cleaning process Pneumatic Control

D. Dynamic State Space Boiler Mode INPUTS

SIG=Signal to fuel and air regulators 
$\mathrm{CV}=$ Governor Valve flow area

$$
\text { PARAMETERS }
$$

$\mathrm{T}_{\mathrm{W}}=$ Water wall time constant.

$\mathrm{C}_{\mathrm{D}} \quad=$ Drum storage capacitance

$\mathrm{C}_{\mathrm{SH}}=$ Super heater storage capacitance

$\mathrm{K}=$ Friction drop coefficient

$\dddot{\mathrm{i}}_{\mathrm{f}}=$ Fuel system dead time

$\mathrm{T}_{\mathrm{f}}=$ Fuel system time constant

STATES

$\dot{Q}=$ Furnace Heat release

$m_{w}=$ Mass flow rate of steam generated in water

Walls (riser) entering the drum.

$\mathrm{P}_{\mathrm{T}}=$ Super heater steam pressure at governor valve.

$\mathrm{P}_{\mathrm{D}}=$ Saturated steam pressure in the drum

\section{Internal Variables}

$\mathrm{m}=$ Mass flow rate of steam from drum to Super heater.

$$
\begin{aligned}
& \text { Algebric Eqution } \\
& \dot{m}=\mathbf{K}^{\sqrt{\mathbf{P}_{\mathbf{D}}-\mathbf{m}_{\mathbf{T}}}} \\
& \dot{m}_{\mathbf{s}}=\mathrm{CV} * \mathrm{P}_{\mathrm{T}} \\
& \frac{d}{d t} \sum=\frac{1}{\mathrm{~T}_{\mathrm{f}}}\left[\operatorname{SIG}\left(t-\mathrm{T}_{\mathrm{f}}\right)-e\right] \\
& \frac{d}{d t} m_{w}=\frac{1}{T w}\left[\dot{Q}-m_{w}\right] \\
& \frac{d}{d t} \mathrm{P}_{\mathrm{T}}=\frac{1}{\mathrm{C}_{\mathrm{SH}}}\left[\dot{m}-\dot{m}_{\mathrm{S}}\right] \\
& \frac{d}{d t} \mathbf{P}_{\mathbf{D}}=\frac{1}{C_{\mathbf{D}}}\left[\dot{m}_{w}-\dot{m}\right]
\end{aligned}
$$

\section{Differential Equations}

\section{E. Outputs}

$\dot{m}_{\mathbf{s}}=\quad$ Superheated Steam mass flow rate to high pressure turbine stage from the above, by setting the state time derivatives to zero it is straight forward to obtain the condition for steady state equilibrium as. H.Steady State Boiler Model

$$
\begin{aligned}
& \dot{Q}=m_{w}=\dot{m}=\dot{m}_{\mathbf{s}}=\text { SIG } \\
& \mathrm{P}_{\mathrm{T}}=\mathrm{SIG} / \mathrm{CV} \\
& \mathrm{P}_{\mathrm{D}}=(\mathrm{SIG} / \mathrm{K})^{2}+\mathrm{SIG} / \mathrm{CV} .
\end{aligned}
$$

Main assumption and features of the model along with some components on these follow. $[11,12,13]$

1) Heat release in the furnace as a function of the fuel and air input signal is determined by the fuel system dynamics lags and dead-times associated with coal feeder and pulverizes.

2) The mass flow of steam from the drum to the super heater is proportional to the square root of the pressure drop between the drum and the Super heater.

3) The steam mass flow to the high pressure turbine stage is regulated by the governor valve. 
E. Collection Of CSTPS Data

$\mathrm{UHR}=$ Unit Heat Rate $(\mathrm{Kcal} / \mathrm{Kwh})$

$\eta_{0}=$ Overall Plant Efficiency

C1, C2, C3 = Capacity of the Individual unit or station (MW)

$\mathrm{SHR}=$ Station Heat Rate (Kcal/Kwh)

HR1, HR2, HR3 = Heat Rate of Individual Unit (Kcal/Kwh)

$\mathrm{FO}=$ Forced Outages

CF1HF1, CF2HF2 = Outage of Individual Unit

$\mathrm{PM}=$ Planned Maintenance

$\mathrm{CH}=$ Plant Installed Capacity in MW

$\mathrm{AP}=$ Auxiliary Power Consumption

$\% \mathrm{C}=\%$ Carbon in Coal

$\mathrm{SEC}=$ Specific Coal Consumption $(\mathrm{Kg} / \mathrm{Kwh})$

Coal Consumption $=$ Sp. Coal Consumption $*$ Total Generation $=(\mathrm{Kg} / \mathrm{KWh}) * \mathrm{KWh}$ 
TABLE IV

\begin{tabular}{|c|c|c|c|c|c|c|c|c|c|c|c|}
\hline ear & $\begin{array}{l}\text { Generati } \\
\text { on in } \\
\text { MUS }\end{array}$ & $\begin{array}{l}\text { Auxiliar } \\
\mathrm{y} \\
\text { Consum } \\
\text { ption in } \\
\text { MUS }\end{array}$ & $\begin{array}{l}\text { Net } \\
\text { Generati } \\
\text { on in } \\
\text { MUS }\end{array}$ & $\begin{array}{l}\% \\
\mathrm{Au} \\
\mathrm{x} . \\
\mathrm{Co} \\
\mathrm{ns} .\end{array}$ & $\begin{array}{l}\text { Coal } \\
\text { consum } \\
\text { ed in } \\
(\mathrm{MT})\end{array}$ & $\begin{array}{l}\text { Spe. } \\
\text { coal } \\
\text { cons } \\
\text { umed } \\
(\mathrm{Kg} / \\
\text { Kwh } \\
)\end{array}$ & $\begin{array}{l}\% \\
\mathrm{PL} \\
\mathrm{F}\end{array}$ & $\begin{array}{l}\% \\
\mathrm{AV} \\
\mathrm{F}\end{array}$ & $\begin{array}{l}\text { Oil } \\
\text { Con } \\
\text { su. } \\
\text { in } \\
(\mathrm{KL})\end{array}$ & $\begin{array}{l}\text { Spe.O } \\
\text { il } \\
\text { cons. } \\
\text { (ML/ } \\
\text { KWH } \\
\text { ) }\end{array}$ & $\begin{array}{l}\mathrm{CO} 2 \\
\text { emitted } \\
\text { per year } \\
\text { (M.T). }\end{array}$ \\
\hline $\begin{array}{l}1998- \\
99\end{array}$ & $\begin{array}{l}13430.8 \\
53 \\
\end{array}$ & $\begin{array}{l}1080.81 \\
47 \\
\end{array}$ & $\begin{array}{l}12350.0 \\
3\end{array}$ & 8.1 & 9624798 & 0.72 & $\begin{array}{l}65 . \\
5 \\
\end{array}$ & $\begin{array}{l}80 . \\
45 \\
\end{array}$ & $\begin{array}{l}3210 \\
8 \\
\end{array}$ & 2.391 & $\begin{array}{l}1203099 \\
7.5\end{array}$ \\
\hline $\begin{array}{l}99- \\
2000 \\
\end{array}$ & $\begin{array}{l}15815.2 \\
97\end{array}$ & $\begin{array}{l}1199.63 \\
2\end{array}$ & $\begin{array}{l}15815.2 \\
97\end{array}$ & 7.6 & $\begin{array}{l}1109942 \\
6\end{array}$ & 0.7 & $\begin{array}{l}76 . \\
9 \\
\end{array}$ & $\begin{array}{l}88 . \\
86 \\
\end{array}$ & $\begin{array}{l}1766 \\
4 \\
\end{array}$ & 1.117 & $\begin{array}{l}1387428 \\
2.5\end{array}$ \\
\hline $\begin{array}{l}2000- \\
01\end{array}$ & $\begin{array}{l}15555.5 \\
86\end{array}$ & $\begin{array}{l}1187.67 \\
88\end{array}$ & $\begin{array}{l}14367.9 \\
07\end{array}$ & 7.6 & $\begin{array}{l}1104947 \\
5\end{array}$ & 0.71 & $\begin{array}{l}75 . \\
9\end{array}$ & $\begin{array}{l}87 . \\
44\end{array}$ & $\begin{array}{l}2099 \\
7 \\
\end{array}$ & 1.35 & $\begin{array}{l}1381184 \\
3.5\end{array}$ \\
\hline $\begin{array}{l}2001- \\
02\end{array}$ & $\begin{array}{l}16227.2 \\
76\end{array}$ & $\begin{array}{l}1240.82 \\
51\end{array}$ & $\begin{array}{l}14986.4 \\
5\end{array}$ & 7.7 & $\begin{array}{l}1206111 \\
0\end{array}$ & 0.74 & $\begin{array}{l}79 . \\
2\end{array}$ & $\begin{array}{l}90 . \\
25\end{array}$ & $\begin{array}{l}2390 \\
0\end{array}$ & 1.473 & $\begin{array}{l}1507638 \\
7.5\end{array}$ \\
\hline $\begin{array}{l}2002- \\
03\end{array}$ & $\begin{array}{l}15179.4 \\
86\end{array}$ & $\begin{array}{l}1168.80 \\
33\end{array}$ & $\begin{array}{l}14010.6 \\
82\end{array}$ & 7.7 & $\begin{array}{l}1089915 \\
9\end{array}$ & 0.72 & $\begin{array}{l}74 . \\
1\end{array}$ & $\begin{array}{l}85 . \\
45 \\
\end{array}$ & $\begin{array}{l}1796 \\
5\end{array}$ & 1.184 & $\begin{array}{l}1362394 \\
8.8\end{array}$ \\
\hline $\begin{array}{l}2003- \\
04\end{array}$ & $\begin{array}{l}16227.4 \\
16\end{array}$ & $\begin{array}{l}1241.78 \\
05\end{array}$ & $\begin{array}{l}14985.6 \\
3\end{array}$ & 7.7 & $\begin{array}{l}1165643 \\
9\end{array}$ & 0.72 & 79 & $\begin{array}{l}88 . \\
88\end{array}$ & $\begin{array}{l}1667 \\
6\end{array}$ & 1.028 & $\begin{array}{l}1457054 \\
8.8\end{array}$ \\
\hline $\begin{array}{l}2004- \\
05\end{array}$ & $\begin{array}{l}15923.7 \\
4\end{array}$ & $\begin{array}{l}1229.10 \\
63\end{array}$ & $\begin{array}{l}14694.6 \\
33\end{array}$ & 7.7 & $\begin{array}{l}1223722 \\
4\end{array}$ & 0.77 & $\begin{array}{l}77 . \\
7\end{array}$ & $\begin{array}{l}86 . \\
88\end{array}$ & $\begin{array}{l}1346 \\
6\end{array}$ & 0.846 & $\begin{array}{l}1529653 \\
0\end{array}$ \\
\hline $\begin{array}{l}2005- \\
06\end{array}$ & $\begin{array}{l}13987.1 \\
94\end{array}$ & $\begin{array}{l}1089.45 \\
13\end{array}$ & $\begin{array}{l}12897.7 \\
42\end{array}$ & 7.8 & $\begin{array}{l}1028489 \\
7\end{array}$ & 0.74 & $\begin{array}{l}68 . \\
2\end{array}$ & $\begin{array}{l}76 . \\
12\end{array}$ & $\begin{array}{l}1618 \\
1\end{array}$ & 1.157 & $\begin{array}{l}1285612 \\
1.3\end{array}$ \\
\hline $\begin{array}{l}2006- \\
07\end{array}$ & $\begin{array}{l}13160.8 \\
81\end{array}$ & $\begin{array}{l}1066.76 \\
97\end{array}$ & $\begin{array}{l}12094.1 \\
11\end{array}$ & 8.1 & $\begin{array}{l}1030285 \\
7\end{array}$ & 0.78 & $\begin{array}{l}64 . \\
2 \\
\end{array}$ & $\begin{array}{l}71 . \\
34 \\
\end{array}$ & $\begin{array}{l}1270 \\
8\end{array}$ & 0.966 & $\begin{array}{l}1287857 \\
1.3\end{array}$ \\
\hline $\begin{array}{l}2007- \\
08\end{array}$ & $\begin{array}{l}15861.5 \\
74\end{array}$ & $\begin{array}{l}1172.99 \\
46\end{array}$ & $\begin{array}{l}14688.5 \\
79\end{array}$ & 7.4 & $\begin{array}{l}1251315 \\
9\end{array}$ & 0.79 & $\begin{array}{l}77 . \\
2\end{array}$ & $\begin{array}{l}90 . \\
18\end{array}$ & $\begin{array}{l}1310 \\
9 \\
\end{array}$ & 0.826 & $\begin{array}{l}1564144 \\
8.8\end{array}$ \\
\hline $\begin{array}{l}2008- \\
09\end{array}$ & $\begin{array}{l}15004.0 \\
81\end{array}$ & $\begin{array}{l}1206.49 \\
56\end{array}$ & $\begin{array}{l}13797.5 \\
85\end{array}$ & 8 & $\begin{array}{l}1217778 \\
7\end{array}$ & 0.81 & $\begin{array}{l}73 . \\
2\end{array}$ & $\begin{array}{l}90 . \\
86\end{array}$ & $\begin{array}{l}2360 \\
6\end{array}$ & 1.573 & $\begin{array}{l}1522223 \\
3.8\end{array}$ \\
\hline $\begin{array}{l}2009- \\
10\end{array}$ & $\begin{array}{l}14622.7 \\
43\end{array}$ & $\begin{array}{l}1238.85 \\
08\end{array}$ & $\begin{array}{l}13383.8 \\
92\end{array}$ & 8.5 & $\begin{array}{l}1202421 \\
4\end{array}$ & 0.87 & $\begin{array}{l}52 . \\
8 \\
\end{array}$ & $\begin{array}{l}73 . \\
81\end{array}$ & $\begin{array}{l}4912 \\
1 \\
\end{array}$ & 4.535 & $\begin{array}{l}1503026 \\
7.5\end{array}$ \\
\hline $\begin{array}{l}2010- \\
11\end{array}$ & $\begin{array}{l}10832.3 \\
77\end{array}$ & $\begin{array}{l}1086.97 \\
32\end{array}$ & $\begin{array}{l}9745.40 \\
3\end{array}$ & 10 & 9461351 & 0.87 & $\begin{array}{l}52 . \\
8\end{array}$ & $\begin{array}{l}73 . \\
81\end{array}$ & $\begin{array}{l}4912 \\
1\end{array}$ & 4.535 & $\begin{array}{l}1182668 \\
8.8\end{array}$ \\
\hline $\begin{array}{l}2011- \\
12\end{array}$ & $\begin{array}{l}13515.8 \\
66\end{array}$ & $\begin{array}{l}1306.03 \\
8\end{array}$ & $\begin{array}{l}12209.8 \\
28\end{array}$ & 9.7 & $\begin{array}{l}1177767 \\
2\end{array}$ & 0.87 & $\begin{array}{l}65 . \\
8\end{array}$ & $\begin{array}{l}86 . \\
14\end{array}$ & $\begin{array}{l}2165 \\
4\end{array}$ & 1.602 & $\begin{array}{l}1472209 \\
0\end{array}$ \\
\hline $\begin{array}{l}2012- \\
13\end{array}$ & $\begin{array}{l}14066.8 \\
22\end{array}$ & $\begin{array}{l}1320.27 \\
32\end{array}$ & $\begin{array}{l}12746.5 \\
48\end{array}$ & 9.4 & $\begin{array}{l}1183386 \\
5\end{array}$ & 0.84 & $\begin{array}{l}68 . \\
6\end{array}$ & $\begin{array}{l}90 . \\
58\end{array}$ & $\begin{array}{l}2196 \\
0\end{array}$ & 1.561 & $\begin{array}{l}1479233 \\
1.3\end{array}$ \\
\hline $\begin{array}{l}2013- \\
14\end{array}$ & $\begin{array}{l}11000.2 \\
72\end{array}$ & $\begin{array}{l}1082.49 \\
97\end{array}$ & $\begin{array}{l}9917.77 \\
2\end{array}$ & 9.8 & 9833638 & 0.89 & $\begin{array}{l}53 . \\
7\end{array}$ & $\begin{array}{l}77 . \\
36\end{array}$ & $\begin{array}{l}3311 \\
3\end{array}$ & 3.031 & $\begin{array}{l}1229204 \\
7.5\end{array}$ \\
\hline $\begin{array}{l}2014- \\
15 \\
\end{array}$ & $\begin{array}{l}12507.8 \\
74\end{array}$ & $\begin{array}{l}1122.03 \\
15\end{array}$ & $\begin{array}{l}11385.8 \\
42\end{array}$ & 9 & $\begin{array}{l}1105206 \\
8\end{array}$ & 0.88 & $\begin{array}{l}64 . \\
4\end{array}$ & $\begin{array}{l}88 . \\
73 \\
\end{array}$ & $\begin{array}{l}1648 \\
2\end{array}$ & 1.318 & $\begin{array}{l}1381508 \\
5\end{array}$ \\
\hline $\begin{array}{l}2015- \\
16\end{array}$ & $\begin{array}{l}12164.9 \\
52\end{array}$ & $\begin{array}{l}1006.25 \\
48\end{array}$ & $\begin{array}{l}11158.6 \\
97\end{array}$ & 8.3 & $\begin{array}{l}1039532 \\
3\end{array}$ & 0.86 & $\begin{array}{l}59 . \\
2\end{array}$ & $\begin{array}{l}77 . \\
05\end{array}$ & 9685 & 0.796 & $\begin{array}{l}1299415 \\
3.8\end{array}$ \\
\hline
\end{tabular}




\section{F. Regression Analysis}

Descriptive statics, correlation between various mention parameters, model summary, ANOVA coefficients $\mathrm{a}=$ Predictor (constant),sp oil consumption $\mathrm{ml} / \mathrm{kwh}$, Auxiliary consumption in mus,

Specific Coal consumption in $\mathrm{Kg} / \mathrm{kwh}$, Avf\%, Plf \% net generation in mus, oil consumption in $\mathrm{kl}$, Coal consumed in $\mathrm{mt}$. generation in mus.

$\mathrm{b}=$ depended variable $-\mathrm{CO} 2$ emitted per year M.T.

Multiple Regression analysis was carried out to find out the equation for prediction between dependent $\&$ independent various. The following have been the variable.

1. Independent Variable

2. Dependent Variable

Regression equation generated is as follow:-

$\mathrm{CO}_{2}$ emitted per year in M.T. $=4.284+(0.001$ Auxiliary Consumption $)+5.841 * 10^{-0.05}(\mathrm{Net}$ Generation) $-0.117 * \%$ Auxiliary Consumption $+1.250 *$ Coal.

Consumed $-4.430 *$ (Specific Coal Consumed $)+0.004 * \%$ PLF $-0.002 * \%$ AVF $-2.133 * 10^{-0.005}+$ $0.267 *$ Specific Oil consumption

The value of coefficient of determination, $\mathrm{R} 2$ is 1.0 and is adequate for acceptance of results.

The ANOVA analysis and ' $t$ ' test carried out indicates the confidence level of 95\%

Using the above equation the $\mathrm{CO}_{2}$ emitted can be estimated if values and dependant variable are interred by controlling variable, $\mathrm{CO}_{2}$ emission per year can be reduced which is helping to achieve greener Environment by reducing global warming impact.

\section{ENERGy Audit METHOdOLOGY}

Energy audit is a engineering techniques used to established the pattern of energy use, level of operating efficiency, identify how and where losses are occurring, identify generic design deficiencies, identify process bottle necks, identify performance deterioration, addressing technological obsolesces, addressing chronic operation and maintenance problem, suggest appropriate techniques tpConserve energy along with economic implications and evaluation of performance efficiency helps for renovation and modernization, up gradation.

Energy Audit methodology consists of three phases.

Preliminary Energy Audit

Detailed Energy Audit

Report Preparation.

This is explained with the help of following steps in fig 5 


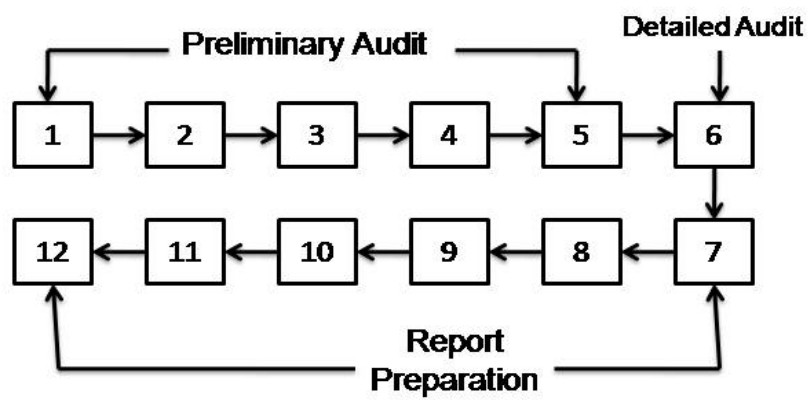

Fig.5 Flow Diagram For Energy Audit Methodology

1. Meeting and discussion with plant officials.

2. Study of Process/ activity of the organization.

3 . Collection of technical details along with drawings.

4. Collection of monthly post data ( $2-3$ yrs.) on Electrical and fuel energy consumption.

5. Action plan for detailed Audit.

6. Performance evaluation of each utility and end use equipment by observation,

7. Conducting tests and measurements.

8. Data analysis, processing, computation, observation of result and comparison with design values.

9. Identifying energy conservation measures and techno economic analysis.

10. Recommendation for energy conservation and preparation of draft report.

11. Submission of draft report to client.

12. Receiving comments from client. \& Submission of mutually agreed final report contains recommendation for improving.

Energy efficiency with cost benefit analysis and action plan.

\section{Performance OptimiZATION PROGRAM METHOdOlOGY FOR IMPLEMENTATION}

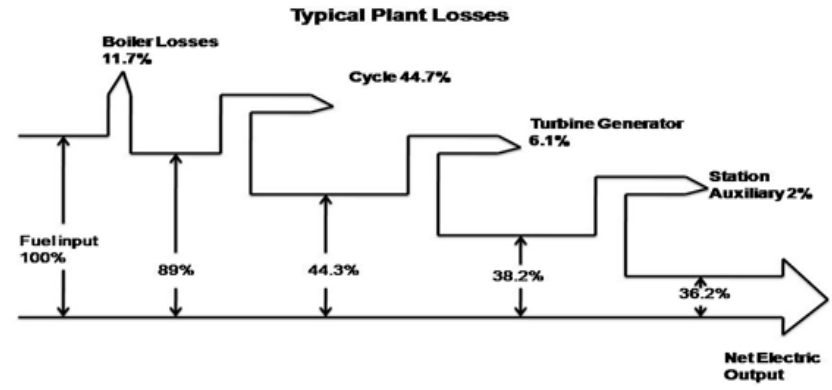

Fig 6. Sankey Diagram For Typical Plant Losses

\section{A. Heat Rate:}

It is a measure of how efficiency a Power Plant converts the chemical energy contained in the fuel into electrical energy. In each of sub-processes, some energy is lost to the environment. Some of the fuel is not burned completely; some of the thermal energy is lost out the stack and rejected to the cooling water, some of the kinetic and mechanical energy products heat instead of electricity, and last, some of the electricity that is produced is used by these sub-processes. Since chemical energy is usually measured in kilocalories (kcal) and electrical energy is usually measured in kilowatt-hours $(\mathrm{kWh})$, the units of heat rate are normally $\mathrm{kcal} / \mathrm{kWh}$.If a power plant converted $100 \%$ of the chemical energy in the fuel into electricity, the plant would have a heat rate of $860 \mathrm{kcal} / \mathrm{kWh}$ 


\section{B. Factor Affecting Heat Rate}

Actual or operating heat rate of a plant gets affected by following factors;

The Initial design. Such as number of stages of feed water heaters, steam driven pumps and fans instead of electric drives, higher initial steam temperature and/pressure are the major design factors which results in a lower heat rate.

- Ambient conditions such as Relative Humidity and Dry Bulb Temperatures affect the condenser cooling water temperature at the out let of cooling towers.

- Load Factor, Conventional power plants are most efficient at full load, and the efficiency decreases as the load decreases.

- The fuel supplied to Boilers. If the coal actually fed to the boiler is deviating from the design coal. This will adversely affect the heat rate.

- How well the plant is operated and maintained Power plants when operated with all the parameters maintained at design levels always operate at Optimum Heat Rate. Correction in Equipment deterioration, shutting off unnecessary auxiliary equipment etc. also improves the heat rate.

\section{NEED OF OPTIMIZATION TEST}

By performing an optimization test, the combination that results in minimizing the unit heat rate can be determined. The periodic performance tests are conducted to:

- $\quad$ Compare the current performance with expected performance

- $\quad$ Predict when and what, equipment maintenance or modification justified or required.

- Evaluate the effectiveness of maintenance work Validate the readings of 'on line' instruments.

- Determine the most efficient operating regime for equipment

- Account for heat rate losses (such as is due to poor turbine efficiency)

Following various tests are carried out

1. HP/IP Turbine Enthalpy Drop Efficiency Test:The purpose of HP/IP Turbine Enthalpy Drop Test is to determine the efficiency of HP and IP sections of the turbine, trend their performance and generate date to pinpoint the probable cause of degradation. The trends can then be used for determination of the optimum point at which the costs incurred due to performance degradation exceed the cost to be incurred for restoration of equipment. It is also used for validation of online instruments.

2. Condenser Performance Test: Condenser tests are done to assess the thermal and hydraulic performance of the condenser in terms of tube fouling, air-in-leakage and to optimize condenser-cleaning schedules. It is also used to trend the performance parameters and generate data to pinpoint the probable cause of degradation. The trends can then be used for deciding the future course of action like tube cleaning schedules, attending air-on-leakage, adequacy of Condenser CW flow, tube replacement programs etc.

3. Feed water Heater Performance Test: The purpose of Feed water heater tests is to assess the current performance and to provide data to assist in optimization of normal operation of the heater. Heater performance can be analyzed by calculating and monitoring Terminal Temperature difference (TTD ), drain Cooler Approach (DCA), the pressure drop on the feed water side and the temperature rise across the heater. These parameters are trended over time for identification of abnormal changes in heater performance and to determine whether corrective action is required to maintain optimum performance.

4. Pump Performance Test: BFP Performance tests are run to compare the current performance of the BFP to its 'expected' performance and also to compare its performance against similar pumps. The parameters to be determined include the total head developed by the pump, the balancing drum leak off flow and the efficiency of the 'train' (I.e. motor, hydraulic coupling and the pump) over the normal operating range. This information can be used to determine, if any corrective maintenance is required immediately or will be required in the future. 
5. Turbine Cycle Heat Rate Test: The purpose of the Turbine Cycle Heat Rate test is to determine overall turbine cycle performance (both heat rate and capability) as well as component thermal performance and to provide a check of accuracy of critical station Instruments. It is used as guidance in scheduling, maintenance outages on the basis of performance trends. It is also used to evaluate major modifications of the turbine or turbine cycle, and changes in operating procedure.

6. Pulverizes Clean Air Test: The second test in a mill performance program is to check to see if each coal pipe is receiving the same amount of primary air. Clean airflow tests are also used to calibrate primary airflow measurement device wherever straight lengths are not available in $\mathrm{P}$ A ducting to the pulverizes.

7. Pulverizes Dirty Air/ Coal Flow Test:The dirty air/coal flow test is usually the third mill performance test (run after obtaining satisfactory results from both the primary air calibration and clean air tests. This test us used to:

- Detect imbalance, if any, in the air and coal flows between the discharges pipes of a Pulverized.

- Collect a representative, iso-kinetic, sample of pulverized coal from different pipes for determination of fineness fractions

- Cross-check the readings of the station Instrumentation e.g. primary airflow through the mill, mill outlet temperature, coal flow through the feeder etc.

8. Air Heaters: Purpose of monitoring of air heater performance is

- To determine air heater leakage rate (the amount of air that leaks to the gas side) which affects station service (fan power) and affects the "indicated" exit gas temperature used in heat rate deviation calculations

- To determine air heater x-ratio (which is an indication of boiler air infiltration, and a craver of AH efficiency)

- To determine air heater gas side efficiency (how well the $\mathrm{AH}$ is transferring heat from the gas side to the air side)

- To validate the station instrument readings e.g. air and gas temperatures, oxygen, air and gas side pressure drops etc.

\section{A. Heat Rate Action Plan}

This section discusses how to take that information and develop an action plan to:

- Ensure that necessary and cost beneficial improvement activities are carried out:

- Set "target" values for parameters (such as boiler outlet Tempand for their heat rate deviations for each unit.

- Predict future values for heat rate deviations and heat rates for strategic planning purposes for individual units, plants, and entire utility systems. Identifying and scheduling a new activity that will affect the heat rate

- $\quad$ Changing the schedule for an activity already in the plan

- If the same activity is planned for several units, after the completion of the first unit, the process indicator target and heat rate deviation target for the remaining units may need to be changed to reflect the values that were achieved.

\section{B. Optimization of Boiler Performance}

For getting optimum performance from the Boiler, it is necessary that controllable losses, such as Dry Flue gas loss and Loss due to incomplete combustion is minimized. Typical values of the losses in the Boiler (designed values) are as shown in table VI.

The effect on heat rate, due to deviation of important parameters from expected values, is listed below in table 7

TABLE: VI

BOILER LOSSES

\begin{tabular}{|c|c|c|}
\hline Loss due to & $\%$ loss & $\begin{array}{l}\text { Whether } \\
\text { controllable }\end{array}$ \\
\hline $\begin{array}{lll}\text { Dry } & \text { Flue Gas } \\
\text { loss } & & \end{array}$ & 4.64 & Controllable \\
\hline
\end{tabular}




\begin{tabular}{|l|l|l|}
\hline $\begin{array}{l}\mathrm{H} 2 \mathrm{O} \text { and } \mathrm{H} 2 \text { in } \\
\text { fuel }\end{array}$ & 5.60 & Not controllable \\
\hline H2O in air & 0.18 & Not controllable \\
\hline Unburnt Carbon & 0.60 & controllable \\
\hline Radiation & 0.19 & Not controllable \\
\hline Unaccounted & 0.40 & Not controllable \\
\hline $\begin{array}{l}\text { Manufacturers } \\
\text { Margin }\end{array}$ & 0.50 & Not controllable \\
\hline Total Losses & 12.11 & \\
\hline Efficiency & 87.9 & \\
\hline
\end{tabular}

TABLE: VII

DEVIATION IN HEAT RATE

\begin{tabular}{|l|l|l|l|l|l|}
\hline Parameter & Expected & Actual & $\begin{array}{l}\text { Excess } \\
\text { Heat/kWh }\end{array}$ & $\begin{array}{l}\text { Excess coal } \\
\text { Consumption } \\
/ \mathrm{kWh} \\
(\mathrm{C} . \mathrm{V} .3500 \\
\mathrm{kcal} / \mathrm{kg})\end{array}$ & $\begin{array}{l}\text { Excess coal } \\
\text { consumption } \\
\text { over the } \\
\text { year, at PLF }\end{array}$ \\
\hline $\begin{array}{l}\text { Excess } \\
\text { Oxygen }\end{array}$ & $3.5 \%$ & $4.0 \%$ & 3.467 & 0.001 & 1600 Tons \\
\hline $\begin{array}{l}\text { Unburnt } \\
\text { Carbon }\end{array}$ & $1.0 \%$ & $1.5 \%$ & 3.782 & 0.0011 & 1700 Tons \\
\hline $\begin{array}{l}\text { FlueGas } \\
\text { Temp }\end{array}$ & 135 & 145 & 18.67 & 0.00533 & 7853 Tons \\
\hline $\begin{array}{l}\text { Moisture } \\
\text { in coal }\end{array}$ & $9 \%$ & $11 \%$ & 2.75 & 00078 & 1156 \\
\hline
\end{tabular}

\section{Mechanism Of Combustion Of Coal:}

In Boilers, due to very high rate of fuel admission, average time a particle stays within the furnace is of the order of 1 to 2 seconds. Hence within this time all the coal particles should burn completely. Combustion is chemical reaction which progresses at a rate determined by

- $\quad$ Time required for combustion of volatile matter.

- $\quad$ Time required for combustion of Coal particle, devoid of volatile matter.

A Combustion of Volatile matter:

On admission of coal in the furnace, intense heat radiation present causes Coal particle temperature to increase rapidly, causing its expansion. The gaseous mater (i.e. the Volatile matter) comes out from the particle and on receiving Oxygen present in the Primary Air, burns out completely. In the process, Oxygen in Primary air gets consumed. The remaining particle, also called soot, now contains Carbon and Noncombustible. Time required for combustion of Volatile matter is 40 to 50 milliseconds. Reaction rate very fast owes to ease of Oxygen in air to mix with gaseous matter. For further combustion of soot particles, secondary air is supplied.

B Combustion of Solid fuel particles:

Soot, being a solid, cannot combine with Oxygen in air readily. In the furnaces, where temperature is above $1000^{\circ} \mathrm{C}$, the rate of combustion of soot particles is governed by the rate at which Oxygen in the 
secondary air reaches to the surface of soot particle. The rate of reaction of coal Particle is given by Reaction Rate $\mathrm{q}=\mathrm{K}_{\text {diff }} \mathrm{p}_{\mathrm{s}}$

Where $K_{\text {diff }}$ is called diffusional reaction rate coefficient and $\mathbf{P}_{\mathbf{S}}$ is the partial pressure of Oxygen in the surrounding gas stream.

$\mathrm{K}_{\mathrm{diff}}=24 \varphi \mathrm{D} / \mathrm{xR}^{\prime} \mathrm{Tm}$

Where, $\varphi=1$ when $\mathrm{CO}_{2}$ is transported from surface

$=2$ when $\mathrm{CO}$ is transported from coal surface

$\mathrm{D}$ is diffusion coefficient of Oxygen in to the gas surrounding the coal particle

$\mathrm{X}$ is particle diameter in $\mathrm{cm}$

$\mathrm{R}^{\prime}$ is gas constant

Tm is mean temperature of the particle

The values of $\mathrm{K}_{\text {diff }}$ are given in following table.

For ensuring complete combustion before the particle leaves the furnace, time available is 1 to 2 seconds. Hence it is necessary that the rate of reaction must be maximum possible. For obtaining high reaction rate, it is therefore necessary that

- $\quad$ Particle size should be as small as possible

- $\quad$ Temperature of the furnace should be as high as possible

- $\quad$ Diffusion coefficient D should be as high as possible

- Concentration of Oxygen in the gases surrounding the particles should be maximum possible leading to maximum Partial pressure of Oxygen,

TABLE VIII

VALUE OF $K_{\text {DIFF }}$ FOR VARIOUS PARTICLE SIZE AND TEMPERATURE

\begin{tabular}{|l|l|l|l|l|l|l|}
\hline \multirow{2}{*}{$\begin{array}{l}\text { Km } \\
\mathrm{K}\end{array}$} & \multicolumn{6}{|l|}{ Particle Diameter, micron } \\
\cline { 2 - 7 } & 25 & 50 & 75 & 100 & 125 & 150 \\
\hline 1000 & .376 & .188 & .125 & .094 & .075 & .063 \\
\hline 1200 & .423 & .211 & .141 & .106 & .085 & .070 \\
\hline 1400 & .466 & .233 & .155 & .117 & .093 & .078 \\
\hline 1600 & .510 & .255 & .170 & .128 & .102 & .085 \\
\hline
\end{tabular}

TABLE IX

DIFFUSION COEFFICIENT D FOR DIFFERENT TYPES OF GASES

\begin{tabular}{|c|c|c|c|c|}
\hline \multirow{2}{*}{$\begin{array}{l}\text { Temperature, } \\
\mathrm{K}\end{array}$} & \multicolumn{4}{|c|}{ Diffusion coefficient } \\
\hline & $\begin{array}{ll}\mathrm{O}_{2} & - \\
\mathrm{N}_{2} & \\
\end{array}$ & $\begin{array}{l}\mathrm{CO}- \\
\mathrm{N}_{2} \\
\end{array}$ & $\begin{array}{l}\mathrm{CO}_{2}- \\
\mathrm{N}_{2} \\
\end{array}$ & $\begin{array}{l}\mathrm{H}_{2} \mathrm{O} \\
-\mathrm{N}_{2} \\
\end{array}$ \\
\hline 1000 & 1.61 & 1.60 & 1.24 & 2.15 \\
\hline 1100 & 1.88 & 1.87 & 1.45 & 2.52 \\
\hline 1200 & 2.17 & 2.15 & 1.68 & 2.92 \\
\hline 1300 & 2.47 & 2.45 & 1.92 & 3.34 \\
\hline 1400 & 2.79 & 2.77 & 2.17 & 3.78 \\
\hline 1500 & 3.13 & 3.10 & 2.42 & 4.25 \\
\hline 1600 & 3.49 & 3.46 & 2.69 & 4.73 \\
\hline
\end{tabular}

It can be seen that, Furnace temperature has a limitation, as it should be below the temperature at which Ash melts. Particle size has a limitation from Coal Mill throughput and economy of pulverization, Diffusion coefficient is constant for the given gas mixture and for the given temperature.

Considering the above limitations, Flame Temperature is generally between 1200 to $1400^{\circ} \mathrm{C}$ for the Indian coal, Particle size is limited to 75 micron, (corresponding to 200 mesh size). The only factor that 
can have some variations is concentration of Oxygen in the gases surrounding the particles. For maintaining the concentration of oxygen high, it is necessary that secondary air must enter at predetermined places and with the design velocity, which is $40 \mathrm{~m} / \mathrm{s}$, i.e. slightly higher than that of Primary air velocity:

C Primary Air Velocity:

Primary air velocity in a coal pope should be such that, coal particles remain air borne and do not separate from the stream. Hence, velocity of $35 \mathrm{mtr} / \mathrm{sec}$ is the optimum velocity to ensure above mentioned requirements. Considering this, manufacturers specify the mass flow rate of primary air to mill, at different mill loading conditions.

Air supply to boiler is such that Oxygen in flue gas is maintained at $3.5 \%$ on dry gas basis at APH outlet.

D Efficiency / Heat Rate Improvement With Available Instruments

In today's world of globalization, commercial aspects regarding any product should be given prime importance. Electrical energy is no exception to this. Cost of Coal is a major factor governing cost of electricity generation in coal fired power plants by optimizing the power plant's operation, with a focus on reducing Heat rate, cost of generation can be reduced to a great extent.

VII WHAT IS HEAT RATE

$$
\text { Efficiency }=\begin{array}{r}
\text { Output } \\
------- \\
\text { Input }
\end{array}
$$

Heat Rate = ---------

Gross elect. Output in KWH

Heat input in Kcal

Net Heat Rate $=$

Net elect. Output in KWH

\section{Method of Calculation:}

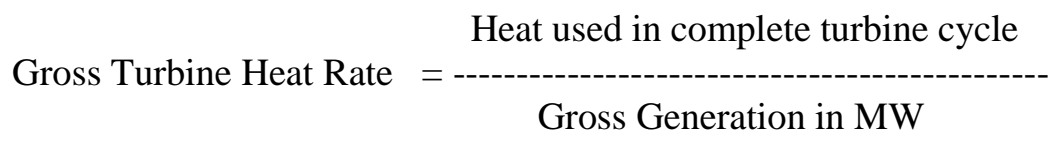

Where,

Heat input at HP Cylinder - Heat in Feed water at Eco. Inlet

Heat used in Turbine Cycle $=+$

$$
\text { (Heat Added in Reheat Cycle) }
$$

Unit Heat Rate

Gross turbine Heat Rate

Boiler Efficiency

\section{Where,}

Boiler efficiency is calculated by 
- Loss Method

- Input / Output Method

Unit Efficiency $=(860 /$ Unit Heat Rate $) * 100$

\section{Savings: Typical Calculations}

Considering Kcal $/ \mathrm{Kwh}$ saved $/$ Unit $\quad=10 \mathrm{Kcal} / \mathrm{kwh}$.

Average Maharashtra state (India) Thermal Generation / Day $=432 \times 10^{6} \mathrm{Kwh}$

Average Coal calorific value $=3300 \mathrm{Kcal} / \mathrm{kwh}$ Average coal cost

Kg. Of coal saved /month

$$
10 \times 432 \times 10^{6} \times 30
$$$$
=
$$

Tons of Coal saved /day

$$
=\frac{10 \times 432 \times 10^{6} \times 30}{3300 \times 1000}=39273
$$
Utility.

Reduction of losses at above different stages will improve Heat Rate and Coal requirement of

Heat rate signifies heat input in Kcal for every unit generated. Improvement of even 25 $\mathrm{Kcal} / \mathrm{Kwh}$ for a $210 \mathrm{MW}$ unit amounts to saving of 4.66 crore per year as shown below.( Total energy requirement of Maharashtra state is $18000 \mathrm{Mw} /$ day )

Heat Rate improved * KWH Generated / year * Coal Cost/ton Amount Saved/year=

$\mathrm{CV} \times 1000$

$$
\frac{25 \times 210 \times 8760 \times 3350}{3300}
$$

\section{$=\quad 4.66 \mathrm{Crore} /$ one $210 \mathrm{mw}$ unit}

(Considering landed coal cost Rs. 3350 /- per ton \& GCV = $3300 \mathrm{Kcal} / \mathrm{Kwh}$ )

As a part of CDM (Clean Development Mechanism) Maharashtra state (As well as in India) started heat rate optimization rigorously through Energy audit Program

TABLE X Factor Affecting Heat Rate Deviation

\begin{tabular}{|l|l|l|l|l|}
\hline $\begin{array}{l}\text { Sr. } \\
\text { No. }\end{array}$ & Factor & $\begin{array}{l}\text { Design/Expected. } \\
\text { Value }\end{array}$ & $\begin{array}{l}\text { Deviation } \\
\text { in Units }\end{array}$ & $\begin{array}{l}\text { Heat Rate } \\
\text { Deviation } \\
\text { in } \\
\text { Kcal/kwh } \\
\text { (approx.,. })\end{array}$ \\
\hline 1 & $\begin{array}{l}\text { M.S. } \\
\text { Pressure }\end{array}$ & $130 \mathrm{Kg} . \mathrm{cm} 2$ & $\begin{array}{l}1 \\
\mathrm{Kg} / \mathrm{cm} 2\end{array}$ & 1.2 \\
\hline 2 & M.S. & $535^{\circ} \mathrm{C}$ & $1^{\circ} \mathrm{C}$ & 1.2 \\
\hline
\end{tabular}




\begin{tabular}{|c|c|c|c|c|}
\hline & Temp. & & & \\
\hline 3 & $\begin{array}{l}\text { Hot R/H } \\
\text { Temp. }\end{array}$ & $535^{\circ} \mathrm{C}$ & $1^{0} \mathrm{C}$ & 1.8 \\
\hline 4 & $\begin{array}{l}\text { Condenser } \\
\text { Vacuum }\end{array}$ & $660 \mathrm{~mm} . \mathrm{Hg}$ & $1 \mathrm{~mm}$ & 2.2 \\
\hline 5 & $\begin{array}{l}\text { Eco. Inlet } \\
\text { Temp. }\end{array}$ & $251^{0} \mathrm{C}$ & $1^{0} \mathrm{C}$ & 1.77 \\
\hline 6 & $\begin{array}{l}\text { Flue Gas } \\
\text { Outlet } \\
\text { Temp. } \\
\text { AH-A }\end{array}$ & $143^{0} \mathrm{C}$ & $1^{0} \mathrm{C}$ & 2.02 \\
\hline 7 & $\begin{array}{l}\text { Flue Gas } \\
\text { Outlet } \\
\text { Temp. } \\
\text { AH-B }\end{array}$ & $143^{\circ} \mathrm{C}$ & $1^{0} \mathrm{C}$ & 2.02 \\
\hline 8 & $\begin{array}{l}\text { Unburnt } \\
\text { in Fly Ash }\end{array}$ & $0.8 \%$ & $1 \%$ & 28.3 \\
\hline 9 & $\begin{array}{l}\text { Unburnt } \\
\text { in Bottom } \\
\text { Ash }\end{array}$ & $4.0 \%$ & $1 \%$ & 3.1 \\
\hline 10 & $\begin{array}{l}\text { RH Spray } \\
\text { Flow }\end{array}$ & 0 Ton/hr. & 1 Ton/hr. & 4.0 \\
\hline
\end{tabular}

TABLE XI

EFFECT OF TURBINE EFFICIENCY ON HEAT RATE

\begin{tabular}{|c|c|c|}
\hline $\begin{array}{l}\text { One } \% \\
\text { Improvement } \\
\text { in Efficiency } \\
\text { on }\end{array}$ & $\begin{array}{l}\% \text { Effect on } \\
\text { Turbine } \\
\text { Cycle Heat } \\
\text { Rate }\end{array}$ & $\begin{array}{l}\text { Effect on Heat } \\
\text { Rate }\end{array}$ \\
\hline HP Turbine & $\begin{array}{ll}0.2 \% & \text { Heat } \\
\text { Rate } & \end{array}$ & $5 \mathrm{kcal} / \mathrm{kwh}$ \\
\hline IP Turbine & $\begin{array}{ll}0.2 \% & \text { Heat } \\
\text { Rate } & \end{array}$ & $5 \mathrm{kcal} / \mathrm{kwh}$ \\
\hline LP Turbine & $\begin{array}{ll}0.5 \% & \text { Heat } \\
\text { Rate } & \end{array}$ & $12.5 \mathrm{kcal} / \mathrm{kwh}$ \\
\hline
\end{tabular}

\section{A. Calculation Of Deviations In Heat Rate Due To Various Factors:}

In table XI, various areas of heat losses are identified which are unavoidable. Loss on account of each factor is tried to be quantified and added to design heat rate for arriving practically achievable heat rate.

Calculations are based on the design data for each unit \& CSTPS as below

Design station heat rate $=$

$\underline{(210 \times 4 \times 2363)+(2 \times 500 \times 2238)+(500 \times 2214)}$

$$
={ }^{2340} 2278 \mathrm{Kcal} / \mathrm{kwh} \text {. }
$$

The design heat rate figures given by manufacturer are based on ideal conditions such as full/stable load, Design coal, No steam/water/Oil leakages, No routine operations like soot blowing, ash evacuation, blow downs, oil support, oil support, oil heating, Ageing effect etc. CHP losses are also not covered in 
this heat rate. In practice however, all these losses are bound to be there and unavoidable. The quantum of these losses is worked out as below one by one.

TABLE XII

CALCULATION OF HEATRATE DEVIATION

\begin{tabular}{|c|c|c|c|c|c|c|c|c|}
\hline Particulars & $\begin{array}{l}\text { Unit } \\
-1\end{array}$ & $\begin{array}{l}\text { Unit- } \\
2\end{array}$ & $\begin{array}{l}\text { Unit- } \\
3\end{array}$ & $\begin{array}{l}\text { Unit- } \\
4\end{array}$ & $\begin{array}{l}\text { Unit- } \\
5\end{array}$ & $\begin{array}{l}\text { Unit- } \\
6\end{array}$ & $\begin{array}{l}\text { Unit- } \\
7\end{array}$ & STN \\
\hline \multicolumn{9}{|l|}{$\begin{array}{l}\text { Design } \\
\text { performance }\end{array}$} \\
\hline $\begin{array}{l}\text { a) Gross heat } \\
\text { rate(Kcal/ } \\
\text { kwh) }\end{array}$ & 2363 & 2363 & 2363 & 2363 & 2238 & 2238 & 2214 & 2278 \\
\hline $\begin{array}{l}\text { b) Boiler } \\
\text { efficiency } \\
(\%)\end{array}$ & $\begin{array}{l}86.3 \\
2\end{array}$ & $\begin{array}{l}86.3 \\
2\end{array}$ & $\begin{array}{l}86.3 \\
2\end{array}$ & $\begin{array}{l}86.3 \\
2\end{array}$ & $\begin{array}{l}88.1 \\
0\end{array}$ & $\begin{array}{l}88.1 \\
0\end{array}$ & $\begin{array}{l}88.0 \\
0\end{array}$ & $\begin{array}{l}87.4 \\
0\end{array}$ \\
\hline $\begin{array}{l}\text { c) Turbine } \\
\text { heat } \\
\text { rate(Kcal } / \mathrm{kg})\end{array}$ & 2040 & 2040 & 2040 & 2040 & 1972 & 1972 & 1948 & 1991 \\
\hline $\begin{array}{l}\text { d) } \mathrm{CV} \text { of } \\
\mathrm{coal}(\mathrm{Kcal} / \mathrm{kg} \\
\end{array}$ & 4313 & 4313 & 4445 & 4445 & 3750 & 3750 & 3500 & 3900 \\
\hline $\begin{array}{l}\text { Sp. Coal } \\
\text { cons }(\mathrm{Kg} / \mathrm{kwh} \\
\text { ) }\end{array}$ & $\begin{array}{l}0.54 \\
8\end{array}$ & $\begin{array}{l}0.54 \\
8\end{array}$ & $\begin{array}{l}0.53 \\
2\end{array}$ & $\begin{array}{l}0.53 \\
2\end{array}$ & $\begin{array}{l}0.59 \\
7\end{array}$ & $\begin{array}{l}0.59 \\
7\end{array}$ & $\begin{array}{l}0.63 \\
2\end{array}$ & $\begin{array}{l}0.58 \\
4\end{array}$ \\
\hline $\begin{array}{l}\text { Design Coal } \\
\text { analysis }\end{array}$ & $\begin{array}{l}\text { Unit- } \\
1 \& 2\end{array}$ & $\begin{array}{l}\text { Unit- } \\
3 \& 4\end{array}$ & $\begin{array}{l}\text { Unit- } \\
5 \& 6\end{array}$ & $\begin{array}{l}\text { Unit- } \\
7\end{array}$ & & & & \\
\hline Moisture (\%) & 8.65 & 8.65 & 8.0 & 10.0 & & & & \\
\hline $\operatorname{Ash}(\%)$ & 30.5 & 35.0 & 40.0 & 42.0 & & & & \\
\hline $\begin{array}{l}\text { Volatile } \\
\text { Mattel }(\%)\end{array}$ & $\begin{array}{l}24.4 \\
8\end{array}$ & $\begin{array}{l}22.3 \\
5\end{array}$ & 24.0 & 22.0 & & & & \\
\hline $\begin{array}{l}\text { Fixed carbon } \\
(\%)\end{array}$ & $\begin{array}{l}36.3 \\
7 \\
\end{array}$ & $\begin{array}{l}34.0 \\
0 \\
\end{array}$ & 28.0 & 26.0 & & & & \\
\hline
\end{tabular}

B Loss Due To Poor Coal Quality:

Coal received at CSTPS is of E/F grade with average proximate analysis as below \& quality is inferior as compared to design coal.

GCV

Moisture

Ash

Volatile matters - 22 to $24 \%$

Hence, there will always be losses on account of poor coal quality which are mainly due high moisture, hydrogen and ash content in coal and coal mill reject.

C Loss Due To Moisture in Coal: Moisture in coal received is in the range of 12 to $18 \%$ depending on season/colliery. In rainy season, moisture is as high as 18 to $19 \%$ i.e. about $10 \%$ more than design value.

Assuming coal factor as $0.72 \mathrm{~kg} / \mathrm{kWh}$,

Heat loss on account of additional moisture of $10 \%$, 
$(0.10 \times 0.72) \times(584+\mathrm{Cp}(\mathrm{T}-\mathrm{t})$ where 584 -Latent heat corresponding to Partial pr. of water vapor. $\mathrm{Cp}=0.45$ (Sp. heat of $\mathrm{S} / \mathrm{H}$ steam) $\mathrm{T}=$ Flue gas temp at $\mathrm{A} / \mathrm{H}$ outlet $(0 \mathrm{c}) \mathrm{T}=$ Ambient temp. (0c) $=0.072 \times$ (584+0.45(150-30)

$=45.94 \mathrm{Kcal} / \mathrm{kWh}$ say $46 \mathrm{kcal} / \mathrm{kwh}$

D Heat Loss Due To Hydrogen In Fuel: Designer has given the loss due to hydrogen in coal as $3.96 \%$ for $210 \mathrm{MW}$ units and $4.28 \%$ for $500 \mathrm{MW}$ units. i.e. Average loss of $4.1 \%$ for station.If $\mathrm{H} 2$ content is worked out by back calculation from this loss i.e.

Loss due to $\mathrm{H} 2(\%)=\underline{9 \times \mathrm{H} 2 \times(548+\mathrm{Cp}(\mathrm{T}-\mathrm{t})}$

$\mathrm{CV}$ of coal

0.041

3900

0.41

$\mathrm{H} 2$

$=\underline{9 \times \mathrm{H} 2 \times(548+0.45(140-30)}$

In design coal analysis of unit-7, designer has mentioned $\mathrm{H} 2$ content of $2.8 \%$, which matches with the $\mathrm{H} 2 \%$ derived as above. Since, facility of $\mathrm{H} 2$ analysis is not available at CSTPS, $\mathrm{H} 2$ content in actual coal received, is derived by empirical formula as below.

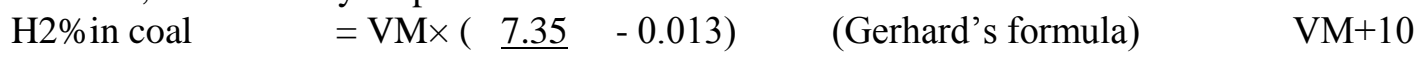

Where VM - Volatile matter in \%

$\mathrm{H} 2(\%)=24 \times(\underline{7.35}-0.013)=4.88 \%$

$24+10$

Heat loss due to excess $\mathrm{H} 2$ in coal

$=9 \times \mathrm{H} 2 \times(548+\mathrm{Cp}(\mathrm{T}-\mathrm{t})$

Where $\mathrm{H} 2-$ quantity of hydrogen $=0.72 \times \underline{(4.88-2.8)}$

100

$=0.015 \mathrm{Kg} / \mathrm{kWh}$.

Heat loss due to excess $\mathrm{H} 2$ in coal

$=9 \times 0.015 \times(548+0.45(150-30)$

$=86.13 \mathrm{Kcal} / \mathrm{kWh}$ say $\underline{\mathbf{8 6 ~ K \mathbf { ~ c a l }} / \mathbf{k w h}}$

4. Loss Due To Sensible Heat In Ash: Ash content in coal is about 40\% as against design value of 30$35 \%$, generating more ash and hence heat loss due to sensible heat of fly ash and bottom ash.

Design coal consumption is $0.548 \mathrm{Kg} / \mathrm{kWh}$

With $35 \%$ ash content, ash generated will be $0.35 \times 0.548=0.2044 \mathrm{Kg} / \mathrm{kWh}$

Actual coal consumption is $0.72 \mathrm{Kg} / \mathrm{kWh}$ and ash content is $40 \%$.

Actual ash generated $=0.288-0.2044=0.0836 \mathrm{Kg} / \mathrm{kWh}$.

Out of total ash generated, $80 \%$ is fly ash and $20 \%$ is bottom ash quantity.

Fly ash quantity $=0.0836 \times 0.8=0.06688 \mathrm{Kg} / \mathrm{kwh}$.

*Heat loss due to sensible heat of bottom ash

$=$ Bottom ash quantity $\times$ Net temp. ofash $\times$ Sp. Heat of bottom ash

$=0.01672 \times 600 \times 0.25 \mathrm{Kcal} / \mathrm{kg} / 0 \mathrm{c}$.

$=2.508 \mathrm{Kcal} / \mathrm{kWh}$.

** Heat loss due to sensible heat of fly ash.

$=$ Fly ash quantity Net temp of fly ash $\times$ Sp. Heat of fly ash.

$=0.06688 \times 140 \times 0.2$

$=1.873 \mathrm{Kcal} / \mathrm{kWh}$.

Total heat loss due to sensible heat of ash $=2.508+1.873=4.381 \mathrm{kcal} / \mathrm{kwh}$.

Say $4 \mathrm{Kcal} / \mathrm{kwh}$.

6.Loss Due To Coal Mill Reject: 
At CSTPS, percentage of coal mill reject generated to coal consumed varies from $0.8 \%$ to $1.8 \%$ with average 1.0 .5 reject, quantity of reject generated per kwh,

$=0.72 \mathrm{~kg} / \mathrm{kWh} \times 0.01$ where 0.72 is coal consumption rate

$=0.0072 \mathrm{Kg} / \mathrm{kWh}$

Calorific value of reject varies between $1000 \mathrm{kcal} / \mathrm{kg}$ to $1100 \mathrm{kcal} / \mathrm{kg}$.

Heat loss on account of reject $=0.0072 \times 1100$

$=7.92 \mathrm{kcal} / \mathrm{kwh} \underline{\text { say } 8 \mathrm{Kcal} / \mathrm{kwh}}$.

\section{E Loss Due To Partial Loading Of The Units:}

Design heat rates at partial loads are higher than design heat rate .Expected heat rates at partial loads for U-1 to U-7 enclosed herewith. Units do not run on full load throughout the year due to various constraints like ageing of the boilers. (18-20 years old units), grid problems, low system demand, wet $\mathrm{coal} /$ choking problem, poor coal quality, plant problems, startup/withdrawal of units. Actual average load of the CSTPS units was as below in table XIII.

TABLE XIII

DEVIATION DUE TO PARTIAL LOADING

\begin{tabular}{|c|c|c|c|c|c|c|c|c|}
\hline Factors & $\begin{array}{l}\text { Uni } \\
\mathrm{t}-1\end{array}$ & $\begin{array}{l}\text { Uni } \\
\mathrm{t}-2\end{array}$ & $\begin{array}{l}\text { Uni } \\
\mathrm{t}-3\end{array}$ & $\begin{array}{l}\text { Uni } \\
\mathrm{t}-4\end{array}$ & $\begin{array}{l}\text { Uni } \\
\mathrm{t}-5\end{array}$ & $\begin{array}{l}\text { Uni } \\
\mathrm{t}-6\end{array}$ & $\begin{array}{l}\text { Uni } \\
\mathrm{t}-7\end{array}$ & $\begin{array}{l}\text { ST } \\
\text { N }\end{array}$ \\
\hline $\begin{array}{l}\text { Rated } \\
\text { capacity } \\
(\mathrm{MW})\end{array}$ & 210 & 210 & 210 & 210 & 500 & 500 & 500 & $\begin{array}{l}234 \\
0\end{array}$ \\
\hline $\begin{array}{l}\text { Average } \\
\text { load } \\
(\mathrm{MW})\end{array}$ & 171 & 169 & 189 & 201 & 454 & 420 & 472 & $\begin{array}{l}207 \\
9\end{array}$ \\
\hline $\begin{array}{l}\text { Heat } \\
\text { rate } \\
\text { expecte } \\
\text { d at } \\
\text { load at } \\
\text { SN. } \quad 2 \\
\text { above }\end{array}$ & $\begin{array}{l}237 \\
8\end{array}$ & $\begin{array}{l}237 \\
9\end{array}$ & $\begin{array}{l}237 \\
2\end{array}$ & $\begin{array}{l}236 \\
7\end{array}$ & $\begin{array}{l}225 \\
8\end{array}$ & $\begin{array}{l}226 \\
5\end{array}$ & $\begin{array}{l}222 \\
2\end{array}$ & $\begin{array}{l}229 \\
0\end{array}$ \\
\hline $\begin{array}{l}\text { Design } \\
\mathrm{HR} \text { at } \\
\text { rated } \\
\text { capacity }\end{array}$ & $\begin{array}{l}236 \\
3\end{array}$ & $\begin{array}{l}236 \\
3\end{array}$ & $\begin{array}{l}236 \\
3\end{array}$ & $\begin{array}{l}236 \\
3\end{array}$ & $\begin{array}{l}223 \\
8\end{array}$ & $\begin{array}{l}223 \\
8\end{array}$ & $\begin{array}{l}221 \\
4\end{array}$ & $\begin{array}{l}227 \\
8\end{array}$ \\
\hline $\begin{array}{l}\text { Deviati } \\
\text { on is } \\
\text { expecte } \\
\text { d H.R. } \\
\text { due to } \\
\text { partial } \\
\text { loading } \\
\text { (Kcal/k } \\
\text { wh) }\end{array}$ & 15 & 16 & 09 & 04 & 15 & 27 & 08 & 12 \\
\hline
\end{tabular}

Thus, a deviation of $\mathbf{1 2} \mathbf{~ K c a l} / \mathbf{k w h}$ _should be considered in station heat rate due to partial loading of the units. 


\section{OTHER LOSSES DUE TO PLANT PROBLEM}

Total heat rate deviation $=\mathrm{A}+\mathrm{B}+\mathrm{C}+\mathrm{D}+\mathrm{E}+\mathrm{F}+\mathrm{G}$

$=144+12+20+21+13+69+76$

$=355 \mathrm{Kcal} / \mathrm{Kwh}$

Hence, Best achievement heat rate of CSTPS is

$$
\begin{aligned}
& =2278+355 \\
& =2633 \mathrm{Kcal} / \mathrm{Kwh} .
\end{aligned}
$$

Say $2635 \mathrm{Kcal} / \mathrm{Kwh}$.

This figure fairly matches with the heat rate worked out as $2622 \mathrm{Kcal} / \mathrm{Kwh}$ based on the actual fuel consumption.

TABLE 19.

LOSS DUE TO TYPICAL PLANT PROBLEM

\begin{tabular}{|l|l|l|}
\hline S.N & Factors responsible for & Deviation in \\
K & heat rate deviation & Kcal/Kwh \\
\hline A & Coal quality & 1 \\
& a) Loss due to moisture & 4 \\
& b) Loss due to hydrogen & 4 \\
& c) Loss due to sensible & 4 \\
& heat in ash & 6 \\
& d) Loss due to coal mill & 8 \\
& rejects & 6 \\
& & 4 \\
\hline B & Partial loading of units & 8 \\
& & 1 \\
\hline C & Ageing factor & 2 \\
& & 0 \\
\hline D & Aux. Steam / Steam, & 2 \\
& water leakages & 1 \\
\hline E & Radiation / unaccounted & 1 \\
& loss & 3 \\
\hline F & Coal handling losses & 6 \\
& & 9 \\
\hline G & Plant problems & 7 \\
& a) Condenser vacuum & 6 \\
& b) Dry flue gas loss & 4 \\
& c) MS / HRH temp & 4 \\
& d) MS pressure & 1 \\
& & 3. \\
& & 5 \\
& & 4 \\
& & 4 \\
\hline
\end{tabular}




\section{CONCLUSIONS}

\section{Factors Affecting Heat Rate Deviation}

As per above discussion study my paper is based on energy Audit study, where suggestion for present energy use reduction on the basis of working experience in TPP is considered. Which shows increase in net generation of TPP and reduction in $\mathrm{CO}_{2}$ emission factor. Actual or operating heat rate of a plant gets affected by following factors;

- The Initial design. Such as number of stages of feed water heaters, steam driven pumps and fans instead of electric drives, higher initial steam temperature and/pressure are the major design factors which results in a lower heat rate.

- Ambient conditions such as Relative Humidity and Dry Bulb Temperatures affect the condenser cooling water temperature at the out let of cooling towers.

- Load Factor, Conventional power plants are most efficient at full load, and the efficiency decreases as the load decreases.

- The fuel supplied to Boilers. If the coal actually fed to the boiler is deviating from the design coal. This will adversely affect the heat rate.

- How well the plant is operated and maintained Power plants when operated with all the parameters maintained at design levels always operate at Optimum Heat Rate. Correction in Equipment deterioration, shutting off unnecessary auxiliary equipment etc. also improves the heat rate.

\section{Benefits Of Heat Rate Improvement}

- Conservation of fuel takes place and money spent for fuel will be reduced. This lowers the cost of producing the electricity.

- The amount of emissions to the environment will be reduced. Improving the heat rate reduces the amount of greenhouse gas that is produced. Less fuel burned means less ash to be disposed of, and less particulate go out of the stack.

- Because less fuel is required to produce the same amount of electricity, the amount of energy on equipment such as pulverizes, coal pipes and nozzles, etc.,is required. Also, along with reduced fuel flows, the air flow is reduced, reducing velocities through the boiler, resulting in less erosion and reduced fan power.

- Frequently, heat rate improvement (such as in the condenser pressure or auxiliary power use) results in an increase in the net generation of the unit, allowing the unit to run at a higher plant load factor. This advantage can be very valuable, especially in the summer when the condenser cooling water temperatures and ambient air temperatures are high, which sometimes results in generation being limited due to condenser pressure or running out of fan(s) capacity.

\section{The Periodic Performance Tests Helps For Decision Making}

- Compare the current performance with expected performance

- Predict when and what, equipment maintenance or modification justified or required. Evaluate the effectiveness of maintenance work Validate the readings of 'on line' instruments.

- Determine the most efficient operating regime for equipment

- Account for heat rate losses (such as is due to poor turbine efficiency)and gas side pressure drops etc. 


\section{REFERENCES}

[1] TERI (2006), National energy map for India Technology Vision 2030, New Delhi.

[2] Climate Change Division (MOEF), New Delhi 2009.

[3] Jeetendrakumar Tiwari ,pawani A.M. "International Journal of science \& nature " ISSN 2229-6441 vol 3(4) 2012( 842-846)

[4] Robertmikulandric,drazenloncar,Dejancvetinovic,Gabrielspiridon,Daniel R. Schneider ,Journal of R \& D Institute for scientific research \& Technological engineering for Automation IPA SA, Bucharest Romania

[5] Mirza hessian hosseinijavedhasanpour university of payamenoor, Tehran ,IPEDR Vol 12( 2011) Singapore Page ( 280-289)

[6] A. Chandra \& H. Chandra " Impact of Indian \& Imported coal on Indian Thermal power plant " Journal of scientific \& Industrial research Vol.63,Feb 2004 PP ( 156-162)

[7] Moti L. Mittal ,chhemendra sharma\&richa singh New Delhi “ Journal of Department of Environmental \& Occupational Health "University of South Florida,Tampa USA.

[8] Ahmadshamshad ,Fulekar M.H. \& Pathak Bhavana " Impact of coal based Thermal power plant on environment \& its mitigation Measures " Int.Res. Journal on Environmental science ISSN 23191414 Vol.1(4) 60-64 Nov 2012.

[9] Anil B. Onkar, "Energy environment implication by reducing SEC in Thermal power Plant (T.P.P.)" Indian journal for environmental protection (Issue Jan 2009)

[10] "Reduction of Green House Gas Emissions through adoption of super critical Technology in Coal fired Thermal Power Plant in India."Sonia Chopra London University, University

[11] Kaminski J. Applied energy, 75 (2003), 3-4, PP.165-172

[12] IEEE Trans-on Power System, Vol (6) No. 1, PP 66-74 feb 1991, de Mello F. P. "Boiler Model for System Dynamic Performance Studies."

[13] IEEE Trans-on energy conversion vol. 6, No. 1, 177-185, March 1991. Kure-Jensen J. and R. Hanisch "Integration of steam turbine controls into Power Plant System".

[14] T.M. Roman, T.A. Lipo "Quantitative analysis of induction motors performance improvement by SCR Voltage control” IEEE trans. In. Appl. VOL I A-19 N.4 1983 P.P. 545-553.

[15] FBlaabjEtal "Can soft starters help to save energy" IEEE Ind. Appl. Magazine Vol-3, 1977. P.P. 56-66.

[16] IEEE standard 519-1992 "IEEE recommended practices \& requirement of Harmonic control in electrical Power System".

[17] Bureau of Indian Standards, Indian Standard code for Motors I5- 1231.

[18] "Operation and application of VFD by Carrier Corporation, Syracuse" New York (Oct-2005).

[19] I. Faiz G. Shagholian. Electro motion 13 (4), 276 (2006)

[20] O.W. Anderson "Optimum design of electrical Machines" IEEE Trans Vol. PAS-86, P.P. 707-711.

[21] C. Singh D. Sarkar "Practical consideration in the optimisation of Induction motor design" IEE Proc-B, Vol-139,No-4.1992

[22] US Department of Energy (USDOE). Fact Sheet: Determing motor load and efficiency developed as part of motor challenge, a programme of USDOE,

[23] K. Idir, etal "A New global optimisation approach for induction motor design" IEEE Canadian Conference Proc. Electrical \& Computer Engineering 1997, P.P. 870-873.

[24] G.O. Garcia "An efficient controller for an adjustable speed induction motor drive" IEEE Trans Ind. Elect. Vol. 41, No 51994 P.P 533-539

[25] CO2 base line Datebase for Indian Power Sector - User Guide, version 11.00, April 2016. (Page 1-34), GOI, MOP, CEA, SewaBhawan, R. K. Puram, New Delhi - 66. 